\title{
Bats (Mammalia, Chiroptera) in the Ponta Grossa region, Campos Gerais, Paraná, Brazil
}

\author{
Cibele M. V. Zanon \& Nélio R. dos Reis \\ 1 Programa de Pós-Graduação em Ciências Biológicas, Departamento de Biologia Animal e Vegetal, Universidade Estadual de \\ Londrina.86051-990 Londrina, Paraná, Brasil. E-mail: cibelezanon@yahoo.com.br
}

\begin{abstract}
The diet, reproduction and activity time of bat species found in Ponta Grossa county, Campos Gerais region, were studied. Collections were conducted in four forest fragments, during 272 hours, on $48 \mathrm{~m}^{2}$ of nets and roosting sites; the total capture effort was $1.52 \cdot 10^{3} \mathrm{~h} . \mathrm{m}^{2}$. Eight species (247 individuals) were registered: Artibeus lituratus (Olfers, 1818), Sturnira lilium (E. Geoffroy, 1810), Desmodus rotundus (E. Geoffroy, 1810) (Phyllostomidae); Tadarida brasiliensis (Desmarest, 1819), Eumops auripendulus (Shaw, 1800) (Molossidae); Eptesicus brasiliensis (Shaw, 1800), Myotis nigricans (Schinz, 1821), and Histiotus velatus (I. Geoffroy, 1824) (Vespertilionidae). The Phyllostomidae family was the most frequently captured. Solanaceae, Moraceae, Piperaceae, and Rosaceae were found in the diet of frugivores; six orders of insects and the class Arachnida were found in the diets of insectivores. Pregnant females were found in September and October and lactating ones in November and December. The collection peak was reached in the second hour-and-a-half. Preservation of the regional forested and altered areas is required for survival of the local chiropterofauna.

KEY WORDS. Bat ecology; forest fragments; Molossidae; Phyllostomidae; Vespertilionidae.
\end{abstract}

RESUMO. Morcegos (Mammalia, Chiroptera) na região de Ponta Grossa, Campos Gerais, Paraná, Brasil. Estudou-se as espécies de morcegos presentes em Ponta Grossa, na região dos Campos Gerais, Paraná, com o objetivo de conhecer seus aspectos ecológicos básicos (dieta, reprodução e horário de atividade). Realizou-se coletas em quatro fragmentos florestais, onde foram empregadas 272 horas de esforço com $48 \mathrm{~m}^{2}$ de redes, e em locais de repouso, totalizando um esforço de captura de $1,52.10^{3} \mathrm{~h} . \mathrm{m}^{2}$. Registrou-se 247 indivíduos, de oito espécies: Artibeus lituratus (Olfers, 1818), Sturnira lilium (E. Geoffroy, 1810), Desmodus rotundus (E. Geoffroy, 1810) (Phyllostomidae); Tadarida brasiliensis (Desmarest, 1819), Eumops auripendulus (Shaw, 1800) (Molossidae); Eptesicus brasiliensis (Shaw, 1800), Myotis nigricans (Schinz, 1821), Histiotus velatus (I. Geoffroy, 1824) (Vespertilionidae). Phyllostomidae foi a família mais capturada. Solanaceae, Moraceae, Piperaceae e Rosaceae fizeram parte da dieta dos frugívoros; constatou-se seis ordens de insetos e a classe Arachnida na dieta dos insetívoros. Fêmeas grávidas foram encontradas nos meses de setembro e outubro; as lactantes, em novembro e dezembro. O maior pico de captura ocorreu na segunda hora e meia de coleta. Faz-se necessário preservar as áreas florestadas, mesmo as já alteradas, pois estas são importantes para a sobrevivência da quiropterofauna local.

PALAVRAS-CHAVE. Ecologia de morcegos; fragmentos florestais; Phyllostomidae; Molossidae; Vespertilionidae.

In recent years, research on bats has become more frequent in the state of Paraná, although the chiropterofauna of approximately two-thirds of the state is still insufficiently known (MiretzKi 2001). In 2001, 80 studies were conducted in the state of Paraná and 56 chiropteran species were registered (ReIs et al. 1993, 1999, Miretzki 2001, Sekiama et al. 2001). The species belong to five families: Phyllostomidae (27 species), Molossidae (13), Vespertilionidae (13), Noctilionidae (2), and Emballonuridae (1).

In the Campos Gerais region, few studies on chiropterans have been conducted, particularly long-term research in specific areas. Campos Gerais is a zonal ecosystem of the sub- tropical steppe biome (WALTER 1986) in terms of climate and topography, and contains a large number of endemic and rare plant species (CERVI \& HATSCHBACH 1990). Therefore, the regional ecosystem is important for the local fauna and must be well known and preserved.

Bats are known to have an important ecological role in nature as biological controllers, pollinators, and predators (FENTON 1990). However, little is known about the ecology of most bat species (their diet, reproduction, and distribution). Considering the scarce information on bats in the Campos Gerais region and the lack of data on bat ecology, we present a list of chiropterofauna species and their diet, reproduction, and activity time. 


\section{MATERIAL AND METHODS}

The Campos Gerais region in Ponta Grossa county, Paraná, is located at $25^{\circ} 50^{\prime} 58^{\prime \prime} \mathrm{S}$ and $50^{\circ} 09^{\prime} 30^{\prime \prime} \mathrm{W}, 800 \mathrm{~m}$ mean altitude. Following the Köppen classification, the predominant climate is $\mathrm{Cfb}$, humid subtropical with mild summers, $18^{\circ} \mathrm{C}$ mean temperature $\left(24^{\circ} \mathrm{C}\right.$ maximum and $13^{\circ} \mathrm{C}$ minimum $)$, and evenly distributed rainfall throughout the year. Winters are colder than in other phyto-ecological areas in the state and frosts are frequent. Average annual rainfall is $1,550 \mathrm{~mm}$ (Mendonça \& Danni-Oliveira 2002).

Collections were conducted in four forest fragments (Fig. 1): Jardim Alphaville, Chácara Zuk, Boca da Ronda, and Fazenda da Praia. The first three are located in the urban area of Ponta Grossa, and the fourth in Tibagi, a county $38 \mathrm{~km}$ from Ponta Grossa. Field collections were conducted monthly from September to December 2001 and from September 2002 to September 2003, a total of 272 collection hours in $48 \mathrm{~m}^{2}$. Bats were collected by using four mist nets (two were $12 \times 2.5 \mathrm{~m}$ wide and two, $7 \times 2.5 \mathrm{~m}$ ), with a total capture effort of 1,52. $10^{3}$ h.m ${ }^{2}$ (Straube \& Bianconi 2002). Following Reis (1984), the nets were checked every 15 minutes to record the exact collection time of specimens.

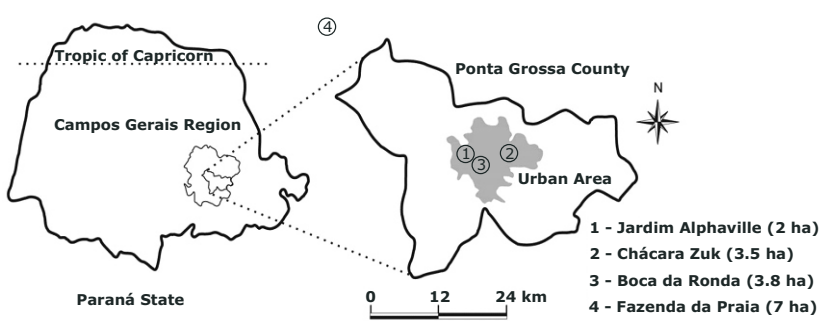

Figure 1. Areas of collection with mist nets in Ponta Grossa, Campos Gerais region, Paraná state.

In urban Ponta Grossa, we conducted daylight collections in bat resting sites (house and building roofs) and in roosts located in their natural environment.

Jardim Alphaville is a 2 ha valley and residencial area of secondary forest where vegetation of the families Anacardiaceae, Asteraceae, Bignoniaceae, Euphorbiaceae, Flacourtiaceae, Lauraceae, Meliaceae, Mimosaceae, Myrtaceae, Rhamnaceae, Rosaceae, Rutaceae, and Sapindaceae are found.

Chácara Zuk, a 3.5 ha altered primary forest fragment, is located approximately $100 \mathrm{~m}$ from a high-traffic avenue and contains plant species of the families Asteraceae, Bignoniaceae, Compositae, Lauraceae, Leguminosae, Meliaceae, Mimosaceae, Myrtaceae, Myrsinaceae, and Solanaceae.

Boca da Ronda is a 3.8 ha and located in a riparian forest fragment that contains a creek with the same name. Species from the Bignoniaceae, Compositae, Euphorbiaceae, Lauraceae, Myrtaceae, Rubiaceae, Sapindaceae, and Solanaceae families
(TAKEDA et al. 1998).

Fazenda da Praia is a 480 ha secondary forest. For this study we selected seven of its forest hectares under remanent riparian Mixed Ombrophylous Forest (MOF) in secondary sucession stage. The area contains vegetative species belonging to the families Arecaceae, Asteraceae, Bignoniaceae, Compositae, Flacourtiaceae, Lauraceae, Melastomataceae, Myrtaceae, Mimosaceae, Monimiaceae, Papilionoideae, Rutaceae, Sapindaceae, Thymelaeaceae, and Ulmaceae.

All four fragments had continuous, disturbed vegetation. Seventeen collections were conducted in each fragment. Nets were placed in between trees and in footpaths in the woods during the first four hours after dark.

Daylight collections in resting sites were conducted manually, with gloves, mask and a spotlight. Bats were identified in the collection site and when in doubt, collectors took the individuals to the lab, where they were killed, placed in formaldehyde at $10 \%$, and preserved in alcohol at 70\%. Specimens were identified according to the keys developed by VieIrA (1942), Vizotto \& Taddei (1973), Jones \& Carter (1976), Reis et al. (1993), and Gregorin \& TAdDei (2002). Voucher specimens are stored in the Museu de Zoologia da Universidade Estadual de Londrina (MZUEL).

Once bats were captured, their feces were collected for identification of the diet items (seeds and remainings of insects) consumed. Roosts were observed for the presence of large, uneaten seeds. These seeds can help identify the plant species that bats feed on and those dispersed by the frugivorous species. Other methods used for studying bat diet included keeping the net-captured animals in small fabric bags until they defecated, and collecting their feces in resting sites. Diet samples of insectivore bats were placed on Petri dishes and diluted in alcohol at $70 \%$; insect fragments were properly separated for identification.

The analysis of secondary sexual characteristics was conducted according to Fleming et al. (1972): the females were touched in the abdomen and their teats were observed for swelling, absence of hair, and milk secretion.

\section{RESULTS}

The 247 individuals captured belonged to eight species (Tab. I) and three families, as follows: three species belong to the family Phyllostomidae, three to the Vespertilionidae, and two to the Molossidae family. The two most frequently netcollected species were Artibeus lituratus and Sturnira lilium. Three of the five species captured with a net belong to the family Phyllostomidae: A. lituratus, S. lilium, and Desmodus rotundus. The other two species belong to the family Vespertilionidae: Myotis nigricans and Eptesicus brasiliensis. In resting sites, 29 specimens were Tadarida brasiliensis (Molossidae), three were Histiotus velatus (Vespertilionidae), and three were Eumops auripendulus (Shaw, 1800) (Molossidae).

The bat species Tadarida brasiliensis and Histiotus velatus

Revista Brasileira de Zoologia 24 (2): 327-332, junho 2007 
Table I. List of species, number and percentage of specimens identified in Ponta Grossa (our study) and number of species identified in a previous study at the Parque Estadual de Vila Velha, Ponta Grossa, Paraná (PEVV).

\begin{tabular}{lcc}
\multicolumn{1}{c}{ Species } & Ponta Grossa & PEVV \\
\hline Phyllostomidae & - & $\mathrm{X}$ \\
Anoura caudifera (E. Geoffroy, 1818) & - & $\mathrm{X}$ \\
Anoura geoffroyi Gray, 1838 & $169-68$ & $\mathrm{X}$ \\
Artibeus lituratus (Olfers, 1818) & - & $\mathrm{X}$ \\
Chrotopterus auritus (Peters, 1856) & $2-0.8$ & $\mathrm{X}$ \\
Desmodus rotundus (E. Geoffroy, 1810) & - & $\mathrm{X}$ \\
Diaemus youngi (Jentink, 1893) & - & $\mathrm{X}$ \\
Diphylla ecaudata Spix, 1823 & - & $\mathrm{X}$ \\
Pygoderma bilabiatum (Wagner, 1843) & $27-11$ & $\mathrm{X}$ \\
Sturnira lilium (E. Geoffroy, 1810) & & \\
Verpertilionidae & $8-3$ & \\
Eptesicus brasiliensis (Desmarest, 1819) & - & $\mathrm{X}$ \\
Eptesicus diminutus Osgood, 1915 & $3-1.2$ & $\mathrm{X}$ \\
Histiotus velatus (I. Geoffroy, 1824) & - & $\mathrm{X}$ \\
Myotis albescens (E. Geoffroy, 1806) & $6-2.4$ & $\mathrm{X}$ \\
Myotis nigricans (Schinz, 1821) & & \\
Molossidae & $3-1.2$ & \\
Eumops auripendulus (Shaw, 1800) & $29-11.2$ & $\mathrm{X}$ \\
Tadarida brasiliensis (I. Geoffroy, 1824) & 8 & 14 \\
\hline Total & & \\
\hline & &
\end{tabular}

were collected from only one colony, in resting sites on a house roof.

Twenty-one feces samples collected from the four fragments were analyzed. The seeds found belong to eight species of Solanaceae, and to one species each of Moraceae, Piperaceae, and of Rosaceae. The diet of A. lituratus contained seven plant species and that of $S$. lilium, eight. The intake of Solanaceae was the highest; however, only Solanum erianthum was consumed by both fructivores, who also consumed Ficus enormis (Moraceae) and Piper gaudichaudianum (Piperaceae). Consumption of Eriobotrya japonica (Rosaceae) was observed only on a roost with five specimens of the A. lituratus species (Tab. II).

Six orders of insects and the class Arachnida (Tab. III) were found in the diets of the four insectivorous species. A large feces sample with a wide variety of insect fragments was obtained in the resting site of a T. brasiliensis colony.

Among all captured specimens, 50.21\% were females. Pregnant females were found in September and October; lactating females, in November and December (Tab. IV).

Nets were observed every 15 minutes, a time that allowed for the identification of the capturing peak during the second hour-and-half of collection (Fig. 2).

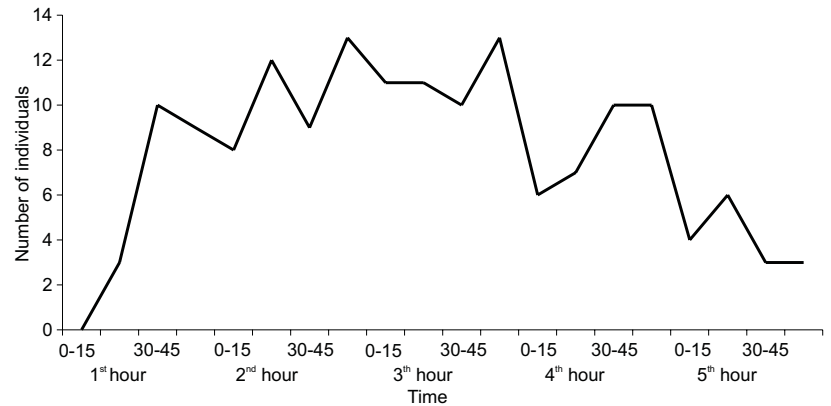

Figure 2. Number of individuals captured with nets during the first four hours after dark.

\section{DISCUSSION}

Artibeus lituratus and Sturnira lilium were the most often net-collected Phyllostomidae. The high abundance can be explained by the fact that the family Phyllostomidae has the highest diversity of species in the neotropical region studied. It can also be explained as a consequence of the methodology used for capturing the two fructivore bats (FENTON et al. 1992), which consisted of placing the mist-nets between 0.5 and $2 \mathrm{~m}$ above ground, where most fruit trees are found (SIPINSKI \& REIS 1995). On the other hand, insectivore species fly in several forest strata (BERNARD 2002).

Two molossidea species were captured in resting sites: Tadarida brasiliensis and Eumops auripendulus. Although the climate and forest formation of the neighboring counties Curitiba and Ponta Grossa are similar, Eumops hansae Saborn, 1932 and E. bonariensis (Peters, 1874) were only found in Curitiba, whereas E. auripendulus was not.

Artibeus lituratus and S. lilium were $79 \%$ of all captured individuals in our study, showing the species' adapting potential also in degraded forest areas or near urban environments. These species can adapt their needs to the local environment, invade the new habitat, and threaten more sensitive species, thus probably disturbing forest remanents when in large numbers (Fenton et al. 1992).

Some species, such as Noctilio leporinus (Linnaeus, 1758), Carollia perspicillata (Linnaeus, 1758), Eptesicus furinalis (d'Orbigny, 1847), Lausirus blossevillii sp (Muller, 1776), Myotis ruber, and Molossus rufus E. Geoffroy, 1805, have been registered in other phytoecological areas in the state of Paraná, except for the Campos Gerais region (Reis et al. 2000). In our study, these same species were absent probably due to vegetation degradation in the region. Myotis albescens was collected only near the Parque Estadual de Vila Velha (Thomas 1899).

High consumption of Solanum by four species of $A$. lituratus $(71.41 \%)$ and five species of S. lilium (88.88\%) was observed. The only solanacea consumed by the two frugivorous bats was Solanum erianthum. The solanacea found in urban Ponta Grossa belonged to the genuses Cestrum, Physalis, and Solanum (TAKEDA et al. 1998); those found in the low-Tibagi

Revista Brasileira de Zoologia 24 (2): 327-332, junho 2007 
Table II. Number of samples (N) from the four fragments and percentage of plant species in the diets of Artibeus lituratus and Sturnira lilium.

\begin{tabular}{|c|c|c|c|c|}
\hline \multirow{2}{*}{ Plant species } & \multicolumn{2}{|c|}{ Artibeus lituratus } & \multicolumn{2}{|c|}{ Sturnira lilium } \\
\hline & $\mathrm{N}$ & $\%$ & $\mathrm{~N}$ & $\%$ \\
\hline \multicolumn{5}{|l|}{ Solanaceae } \\
\hline Solanum megalochiton Mart. & 1 & 10 & 0 & 0 \\
\hline Solanum granulosoleprosum Dunal & 0 & 0 & 1 & 9,1 \\
\hline Solanum americanum Hil. & 0 & 0 & 1 & 9,1 \\
\hline Solanum erianthum D. Don. & 1 & 10 & 4 & 36,3 \\
\hline Solanum sisymbrifolium Lam. & 1 & 10 & 0 & 0 \\
\hline Solanum ciliatum Lam. & 0 & 0 & 1 & 9,1 \\
\hline Solanum gemellum Mart. ex Sendtn & 1 & 10 & 0 & 0 \\
\hline Vassobia breviflora (Sendtn.) A.T. Kunz & 0 & 0 & 1 & 9,1 \\
\hline \multicolumn{5}{|l|}{ Moraceae } \\
\hline Ficus enormis (Mart. ex Miq) Miq. & 2 & 20 & 2 & 18,2 \\
\hline \multicolumn{5}{|l|}{ Piperaceae } \\
\hline Piper gaudichaudianum Kunth & 3 & 30 & 1 & 9,1 \\
\hline \multicolumn{5}{|l|}{ Rosaceae } \\
\hline Eriobotrya japonica (Thumb.) Lindl. & 1 & 10 & 0 & 0 \\
\hline Total number of plants & 10 & 100 & 11 & 100 \\
\hline Total of plant species per bat species & 7 & & 7 & \\
\hline
\end{tabular}

Table III. Items found in the diet of insectivorous bats.

\begin{tabular}{lcccc}
\hline & \multicolumn{3}{c}{ Number of samples } \\
\cline { 2 - 5 } & Myotis nigricans & Eptesicus brasiliensis & Histiotus velatus & Tadarida brasiliensis \\
\hline Diptera & 2 & 2 & 0 & $*$ \\
Coleoptera & 2 & 2 & 0 & $*$ \\
Hemiptera & 0 & 0 & 0 & $*$ \\
Hymenoptera & 1 & 2 & 0 & $*$ \\
Lepidoptera & 2 & 0 & 0 & 0 \\
Orthoptera & 1 & 0 & 1 & 71 \\
Insect fragments & 3 & 2 & 2 & 71 \\
Total number of insects & 11 & 8 & 0 & 0 \\
Class Arachnida & 2 & 0 & 2 & 1 \\
\hline Total of items per species & 7 & 4 &
\end{tabular}

* Several samples collected in a shelter.

river area, which includes the Campos Gerais region, belonged to the genuses Lycianthes and Vassobia.

Solanacea fruits are known food resources for bats (Peracchi \& Albuquerque 1971, Uieda \& Vasconcellos Neto 1985). These fruits have a pulpous placenta and small loculi full of a juicy substance (BARROso et al. 1999); the seeds are small and numerous and can be dispersed by bats (CHARLEs-DOMINIQUE 1986). According to Moro (2001), a large number of Mixed Ombrophylous Forest (MOF) trees and shrubs have small and round fruits that birds, bats and small animals appreciate. The high ingestion of Solanum by A. lituratus and S. lilium in our study suggests that the genus became the main food resource for both bat species due to the lack of other edible products in the region.

Ficus enormis and $F$. landerstiana, which belong to the family Moraceae (TAKEDA et al. 1998), are found in the Campos Gerais region and are potential food resources for bats. Only Ficus enormis was consumed by A. lituratus and S. lilium. Marinho- 
Table IV. Sex and reproduction stage of bats collected in different seasons in Ponta Grossa, Campos Gerais region, Paraná.

\begin{tabular}{|c|c|c|c|c|c|c|c|c|c|c|}
\hline \multirow{2}{*}{ Bat Species } & \multicolumn{2}{|c|}{ Preliminary study/2001 } & \multicolumn{2}{|c|}{ Spring/2002 } & \multicolumn{2}{|c|}{ Summer/2003 } & \multicolumn{2}{|c|}{ Fall/2003 } & \multicolumn{2}{|c|}{ Winter/2003 } \\
\hline & Female & Male & Female & Male & Female & Male & Female & Male & Female & Male \\
\hline \multirow[t]{3}{*}{ Artibeus lituratus } & $0 / 14$ & $3 / 24$ & $0 / 21$ & $0 / 26$ & $0 / 10$ & $0 / 11$ & $0 / 5$ & $0 / 9$ & $0 / 14$ & $0 / 16$ \\
\hline & $1 \mathrm{~F}$ & & & & $3 \mathrm{~L}$ & & & & & \\
\hline & $11 \mathrm{~L}$ & & & & & & & & & \\
\hline \multirow[t]{2}{*}{ Sturnira lilium } & $1 / 5$ & $0 / 2$ & $0 / 3$ & $0 / 4$ & $0 / 1$ & $0 / 3$ & $0 / 1$ & $0 / 1$ & $0 / 3$ & $0 / 1$ \\
\hline & $2 \mathrm{~L}$ & & & & $1 \mathrm{~L}$ & & & & & \\
\hline Desmodus rotundus & & & & & & & & $0 / 1$ & $0 / 1$ & \\
\hline Eptesicus brasiliensis & $2 / 3$ & $0 / 1$ & $2 / 2$ & & $0 / 1$ & & & & $0 / 1$ & \\
\hline Histiotus velatus & & & & & $2 / 2$ & & & & & $0 / 1$ \\
\hline \multirow[t]{2}{*}{ Myotis nigricans } & $1 / 1$ & & $1 / 2$ & & & $0 / 1$ & & & & \\
\hline & & & $1 \mathrm{~L}$ & & & & & & & \\
\hline Eumops auripendulus & & & & & & $0 / 2$ & & & & $0 / 1$ \\
\hline Tadarida brasiliensis & $1 / 1$ & $0 / 1$ & $2 / 3$ & $0 / 1$ & $0 / 1$ & & $0 / 7$ & $0 / 1$ & $0 / 1$ & $0 / 13$ \\
\hline
\end{tabular}

(/) Pregnant or apparent testicle cimens/collected individuals; (L) lactating females; (F) offspring.

FilHo (1991), Reis et al. (1993), SipInSKi \& ReIs (1995), and BizERRIL $\&$ RAw (1998) found that piperaceae fruits with small seeds are important diet components for Carollia perspicillata. In our study, ingestion of Piper gaudichaudianum was recorded for $A$. lituratus and S. lilium. A. lituratus also fed on the fruits containing large seeds, but not on the seeds themselves. Eryobothrya japonica was found in one of the roosts, which suggests that bats take fruits of this species far from their place of origin, thus contributing to seed germination (PIJL 1972).

Bats interact positively with several plants as seed dispersers. Because of this important role of bats, fruits of these plants are called chiropterocoric. The chiropterocory and chiropterophylly symptoms refer to plants that are, respectively, dispersed and pollinated by bats. These syndromes are very important in tropical forests, where several plants can not be dispersed by other animals, and therefore, adapt themselves morphologically for dispersion by bats (PIJL 1972).

In our study, collections were conducted during the first four hours after dark, and there were more bats during the second hour-and-half of the collections done during the first hours after dark, as also found by ERKERT (1982). Other factors to be considered in defining bat activity patterns are social behaviour, reproduction pattern, and the intra- and inter-specific interactions for food consumption (BERNARD 2002).

Brazil has a wide variety of bat species, and southern Brazil is one of the most studied regions for the subject. However, some areas in Paraná lack knowledge about bat ecology. Among them, the Campos Gerais region, where agriculture caused largescale deforestation and the habitats for bats and other mammals were severely damaged. Therefore, all forest fragments must be preserved, even when already altered, to ensure survival of the local chiropterofauna.

\section{REFERENCES}

Barroso, G.M.; M.P. Morin; A.L. Рeixoto \& C.L.F. Ichaso. 1999. Frutos e sementes. Morfologia aplicada à sistemática de dicotiledôneas. Viçosa, Universidade Federal de Viçosa, 443p. BERNARD, E. 2002. Diet, activity and reproduction of bat species (Mammalia, Chiroptera) in Central Amazonia, Brazil. Revista Brasileira de Zoologia 19 (1): 173-188.

Bizerril, M.X.A. \& A. RAw. 1998. Feeding behaviour of bats and the dispersal of Piper arboreum seeds in Brazil. Journal of Tropical Ecology 14: 109-114.

Cervi, A.C. \& G. Hatschbach. 1990. Flora, p. 26-27. In: C.H. Rocha; V. Michalizen \& A. Pontes Filho. (Eds). Plano de integração do Parque Estadual de Vila Velha - Rio São Jorge. Ponta Grossa, Ituphava S/C, Prefeitura Municipal de Ponta Grossa, 102p.

Charles-Dominique, P. 1986. Inter-relations beetwen frugivorous vertebrates and pioneer plants: Cecropia, birds and bats in French Guyana, p. 119-134. In: A. Estrada \& T.H. Fleming (Eds). Frugivores and seed dispersal. Dordercht, W. Junk Publishers, 398p.

ERKert, H.G. 1982. Ecological aspects of bat activity rhythms, p. 201-242. In: T.H. Kunz (Ed.). Ecology of bats. New York, Plenum Press, XVIII+425p.

Fenton, M.B. 1990. Foraging behavior and ecology of animal eating bats. Canadian Journal of Zoology 68: 411-422.

Fenton, M.B.; L. Acharya; D. Audet; M.B.C. Hickey; C. Merriman; M.K. Овrist; D.M. Syme \& B. Adkins. 1992. Phyllostomid bats (Chiroptera: Phyllostomidae) as indicators of habitat disruption in the neotropics. Biotropcia 24 (3): 440-446.

Fleming, T.H.; E.T. Hooper \& D.E. Wilson. 1972. Three central american bat communities: structure, reproductive cycles, 
and movement patterns. Ecology 53 (4): 555-569.

Gregorin, R. \& V. TAddei. 2002. Chave artificial para a identificação de molossídeos brasileiros (Mammalia-Chiroptera). Journal Neotropical Mammal 9 (1): 13-32.

Jones, J.K. \& D.C. Carter. 1976. Annoted checklist with keys to subfamilies and genera, p. 7-38. In: R.J. BAKER; J.K. JONES JR. \& D.C. CARTER (Eds). Biology of bats the new world family Phyllostomatidae. Part I. Huston, Special Publications Museum Texas Tech University, vol. 10, 218p.

Marinho-Filho, J.S. 1991. The coexistence of two frugivorous bat species and the fenology of their food plants in Brazil. Journal of Tropical Ecology 7 (1): 59-67.

Mendonça, F.A. \& I.M. Danni-Oliveira. 2002. Dinâmica atmosférica e tipos climáticos predominantes da bacia do rio Tibagi, p.63-66. In: M.E. Medri; E. Bianchini; O.A. ShibatTa \& J.A. Pimenta (Eds). A bacia do rio Tibagi. Londrina, Edição dos autores, 595p.

MiretzKi, M. 2001. Bats of Paraná state, Brasil (Mammalia, Chiroptera). Mastozoologia Neotropical/Journal of Neotropical Mammalogy 8 (1): 91-92.

Moro, R.S. 2001. A vegetação dos Campos Gerais da escarpa devoniana, p. 481-503. In: C.H.M. Ditzel \& C.L.L. SAHR (Eds). Espaço e cultura: Ponta Grossa e os Campos Gerais. Ponta Grossa, Editora Universidade Estadual de Ponta Grossa, 518p.

Peracchi, A.L. \& S.T. Albuquerque. 1971. Lista provisória dos quirópteros dos Estados do Rio de Janeiro e Guanabara, Brasil (Mammalia, Chiroptera). Revista Brasileira de Biologia 31 (3): 405-413.

PIJL, L. VAN DER. 1972. Principles of dispersal in higher plants. New York, Springer-Verlag, 153p.

ReIs, N.R Dos. 1984. Estrutura de comunidade de morcegos na região de Manaus, Amazonas. Revista Brasileira de Biologia 44 (3): 247-254.

Reis, N.R dos; M.F. Muller; E.S. Soares \& A.L. Peracchi. 1993. Lista e chave de quirópteros do Parque Estadual Mata dos Godoy e arredores. Londrina-PR. Semina, Ciências Biológicas/Saúde 4 (2): 120-126.

Received in 30.V.2006; accepted in 30.IV.2007.
Reis, N.R. dos; A.L. Peracchi \& M.L. Sekiama. 1999. Morcegos da fazenda Monte Alegre, Telêmaco Borba, Paraná (Mammalia, Chiroptera). Revista Brasileira de Zoologia 16 (2): 501-505.

Reis, N.R. dos; A.L. Peracchi; M.L. Sekiama \& I.P. De Lima. 2000. Diversidade de morcegos (Chiroptera, Mammalia) em fragmentos florestais no estado do Paraná, Brasil. Revista Brasileira de Zoologia 17 (3): 697-704.

Sekiama, M.L., N.R. dos Reis; A.L. Peracchi \& V.J. Rocha. 2001. Morcegos do Parque Nacional do Iguaçu, Paraná (Chiroptera, Mammalia). Revista Brasileira de Zoologia 18 (3): 749-754.

SiPINSKI, E.A.B. \& N.R. Dos ReIs. 1995. Dados ecológicos dos quirópteros da Reserva Volta Velha, Itapoá, Santa Catarina, Brasil. Revista Brasileira de Zoologia 12 (3): 519-528.

Straube, F. C. \& G.V. Bianconi. 2002. Sobre a grandeza e a unidade utilizada para estimar esforço de captura com utilização de redes-de-neblina. Chiroptera Neotropical 8 (1-2): 150152.

TaKeda, I.J.M.; R.S. Moro; R. Kaczmarech; L.C.M. Bahls; M.V. Bourguignon \& E. Schardosin. 1998. Levantamento florístico do Parque Municipal Boca da Ronda, Ponta Grossa, PR. Publicatio UEPG, Ciências Biológicas e da Saúde 1 (4): 49-63.

Thomas, O. 1899. List of the mammals obtained by Dr. Franco Grillo in the Province of Paraná, Brazil. Annali dei Museo Civico di Storia Naturali di Genova 2 (20): 546-549.

Uieda, W. \& J. Vasconcellos Neto. 1985. Dispersão de Solanum spp. (Solanaceae) por morcegos, na região de Manaus, Amazonas, Brasil. Revista Brasileira de Zoologia 2 (7): 449-458.

Vieira, C.O.C. 1942. Ensaio monográfico sobre os quirópteros do Brasil. Arquivos de Zoologia do Estado de São Paulo 3 (8): $1-471$.

VizotTo, L.D. \& V.A. TADDEI. 1973. Chave para determinação de quirópteros brasileiros. Boletim de Cências da Faculdade de Filosofia, Ciências e Letras de São José Rio Preto 1: 172.

WAlter, H. 1986. Vegetação e zonas climáticas. São Paulo, EPU, $326 \mathrm{p}$. 